\title{
MANAJEMEN SUMBERDAYA SANTRI (PESERTA DIDIK) DI PONDOK PESANTREN BAITUL ARQOM BALUNG
}

\author{
Hairul Huda \\ Dosen Program Studi Pendidikan Agama Islam, Fakultas Agama Islam \\ Universitas Muhammadiyah Jember \\ Email : hairulhuda@unmuhjember.ac.id
}

\begin{abstract}
Abstrak.
Santri-i.e., students in Islamic boarding school-resources are one of the elements in the management of Islamic boarding schools. Santri are the first consumer of the service management provided by educational institutions such as Islamic boarding schools. As the main consumer, there is a need for a good and orderly management system for santri so that the objectives of Islamic boarding schools are more directed and can be optimally achieved. Hence, Islamic boarding schools have to carry out resource management for santri so they are able to recruit santri who are truly qualified, are able to adapt, and can put visions and missions of the school into practice. Formulations of this study are as follows: 1. How to design Santri resource planning at Bairul Arqom Islamic Boarding School, Balung? 2. What systems are used for the purpose of recruitment and selection of Santri at Bairul Arqom Islamic Boarding School, Balung? 3. What type of orientation and placement processes of Santri resources are used in Bairul Arqom Islamic Boarding School, Balung?, and 4. How santri resources at Islamic Boarding School Bairul Arqom Islamic Boarding School, Balung, are evaluated? The method used in this study is a qualitative method with data obtained through argumentation. Sources of the data are from interviews, observation and documentation of the data owned by the Islamic boarding school. The results show that activities in santri resource management carried out in Baitul Arqom Islamic boarding school, Balung, are as follows: 1. The design of Santri resource planning is periodically designed and arranged based on the needs and results of discussion among selected committee, 2. Open recruitment patterns involve external sources (e.g., alumni recommendation), and the selection processes involve administrative selection. 3. The orientation is done formally in the form of Khutbatul asry and a week of introduction, 4. Assessment of santri is done in three ways, namely a writing test, speaking test, and daily observation.
\end{abstract}

Kata Kunci : Manajemen Sumberdaya Santri, Pondok Pesantren Islam

\section{PENDAHULUAN}

Salah satu upaya dalam melaksanakan pembangunan nasional dalam bidang pendidikan terutama pendidikan pondok pesantren adalah hal hal yang membahas sumberdaya manusia.
Sumberdaya manusia merupakan sarana yang ampuh dalam melaksanakan dan percepatan pembangunan nasional, melalui pendidikan yaitu dengan cara meningkatkan kualitas sumber daya manusia yang ada di pondok pesantren. Pondok pesantren sebagai salah satu 
bentuk lambaga pendidikan Islam yang juga tidak terlepas dari tujuan pendidikan nasional yang tecantum dalam UndangUndang Sistem Pendidikan Nasional Nomor 20 tahun 2003 tentang Sistim Pendidikan Nasional bahwasannya pendidikan nasional bertujuan mencerdaskan kehidupan bangsa dan mengembangkan manusia Indonesia seutuhnya, yaitu manusia yang beriman dan bertaqwa pada Tuhan Yang Maha Esa dan budi pekerti luhur, memiliki pengetahuan dan ketrampilan, kesehatan jasmani dan rohani, kepribadian yang mantap dan mandiri serta rasa tanggung jawab kemasyarakatan dan kebangsaan. Serta tercantum pula di dalam UU SISDIKNAS No. 20 Th. 2003 Bab II pasal 2 dan 3 menyatakan bahwa: Pendidikan nasional yang berdasarkan Pancasila dan Undang-UndangDasar Negara Republik Indonesia Tahun 1945 berfungsi mengembangkan kemampuan dan membentuk watak serta peradaban bangsa yang bermartabat dalam rangka mencerdaskan kehidupan bangsa, bertujuan untuk mengembangkan potensi peserta didik agar menjadi manusia yang beriman dan bertakwa kepada Tuhan Yang Maha Esa, berakhlak mulia, sehat, berilmu, cakap, kreatif, mandiri, dan menjadi warga negara yang demokratis serta bertanggung jawab.

Sistem Pendidikan Nasional yang telah hidup dan berkembang di masyarakat membuat lembaga pondok pesantren lebih intens dalam berbenak untuk mewujudkan tujuan dari pendidikan nasional yang sudah menyebar kepelosok masyarakat di Negara Indonesia. Hai ini tidak menjadi penghalang bagi lembaga pondok pesantren untuk menciptakan tatanah pendidikan yang membangun dan membaktikan dirinya untuk Negara kesatuan indonesai. Karena pesantren pada dasarnya adalah lembaga pendidika yang menciptakan manusia yang memiliki keadalinan dan mampu bertanggung jawab dalam segala perbuatannya.

Organisasi yang ada di dunia pendidikan dengan sebuah pendekatan manajerial atau pendekatan manajemen yang rapih dan terstruktur, dapat meningkatkan hasil pendidikan yang lebih maju daripada pendekatan individual atau pendekatan pimpinan. Pendekatan pimpinan kerapkali dilakukan didunia pendidikan semacam pesantren. Organisasi pendidikan, dalam meningkatan Kualitas kelembagaan, perlu menelaah beberapa indicatoridikator terkait dengan tolak ukur sebuah keberhasilan. Tolok ukur tersebut dapat kita kasifikasikan dedalam beberapa hal, diantaranya adalah Pertama, melihat seberapa lancar Proses pendidikan yang berjalan di sebuah istitusi pendidikan, Kedua, seberapa besar Kelengkapan penunjang sarana dan prasarana yang dimiliki sebuah institusi pendidikan, Ketiga, budaya membangun Profesionalitas sumber daya manusia yang dimiliki, Keempat, upaya akademik serta nonakademik peserta didik dalam mencapai prestasi dan Kelima, Kualitas manajemen pesantren.

Ketika melihat kelima indicator tersebut di laksanakan dengan benar maka sebuah istitusi akan memiliki kualitas unggulan. Prioritas utama yang harus menjadi acuan diatarana kelima pokok indicator tersebut adalah budaya membangun profesionalisme sumberdaya manusia. Sumberdaya manusia menjadi prioritas utama karena manusia menjadi penggera roda organisasi di setiap institusi, bahkan di dunia pendidikan manusia memiliki peran central mewujudkan visi misi dan tujuan instraksional. Untuk itu manajemen sumber daya manusia menjadi pokok pembahasan.

Sumber Daya Manusia menjadi pokok perhatian utama bagi setiap profesi yang ada di lingkungan masyarakat 
pendidikan. Hal ini, dapat diketahui dari fungsi dan peranserta sumber daya manusia yang menjadi penggerak dalam upaya pembangunan peradaban dunia dan sumberdaya manusia mempunyai arti yang sangat penting dalam menciptakan keberhasilan di sebuat tujuan organisasi. Seperti yang diungkapkan oleh (Sadili Samsudin, 2006 : 9) menurutnya sumber daya manusia merupakan sumber dari kekuatan yang berasal dari manusia yang dapat didayagunakan oleh organisasi atau lembaga dimana sumber daya manusia tersebut merupakan sebuah aset (modal) bagi sebuah organisasi atau lembaga dalam menentukan keberhasilan atau kegagalan organisasi atau lembaga dalam merealisasikan visi misi strateginya. Perlu disadari oleh manusia bahwa peningkatan sumber daya manusia disetiap profesi harus diperhatikan agar tidak terjadi kemerosotan informasi dan tergerus oleh kemajuan zaman.

Sumber daya manusia merupakan bagian terpenting dalam struktur organisasi, lembaga, madrasah, atau di pesantren. Sebuah institusi tidak akan berkembang jika sumber daya manusia yang ada tidak terpilih sesuai dengan kriteria yang diinginkan. Sumberdaya manausia dalam artian orang-orang yang memberikan tenaga, bakat dan kreativitas lainnya kepada pesantren apa bila tidak sesuai dengan apa yang diinginkan pesantren maka visi dan misi pesantren tidak akan tercapai. Apabila sumberdaya manusia yang ada di pesantren tidak memiliki orang-orang yang berkualitas tinggi, serta semangat berjuang yang tinggi, terhadap organisasi yang ada didalam pesantren, maka yang akan terjadi adalah kegagalan dalam mencapai tujuan. Oleh karena itu menjadi seorang pimpinan Pesantren (jika dalam lembaga pendidikan) harus mampu memiliki wewenang dan tanggung jawab untuk melakukan pengrekrutan anggota serta mampu untuk memilih anggota yang tepat agar tujuan pondok pesantren menjadi terlaksana dengan baik dan seimbang. Hal ini sesuai dengan apa yang di katakana oleh bapak Hasibuan. Menurut (hasibuan, 2010:87) rekrutmen merupakan fungsi operasional pertama dalam manajemen sumber daya manusia.

Komponen yang paling utama dan memiliki peranan penting di lembaga Pondok Pesantren adalah Santri (Peserta didik). Secara Struktural Pendidikan, Santri merupakan konsumen awal dari setiap pelayan pendidikan yang diselenggarakan oleh sebuah lembaga pendidikan seperti pesantren. Agar tujuan sebuah institusi tersebut berjalan dengan sesuai rencana perlu dirancang sedemikian rupa perencanaan yang matang terhadap konsumen pertama. Santri perlu di beri stimulus agar mengalami perubahan pola piker dan pembentukan pembelajaran yang kondusif. Dan perubahan sanatri tersebut harusnya mengenai hal-hal yang berhubungan dengan sikap mental yang kuat, keefektifan, efisiensi, produktivitas, dan peran peran fundamental dalam tataran masyarakat agar tidak ketinggalan. Perubahan ini akan menuntut Santri untuk meningkatkan kualitas terhadap pengembangan diri agar dapat menyongsong kehidupan bermasyarakat dan mampu mengantisipasi perubahanperubahan yang akan terjadi di setiap zaman.

Menurut (Sonhaji Soleh, 2005 : 3) Mengenai sumber daya manusia, sebenarnya dapat dilihat dari dua aspek, yakni kuantitas dan kualitas. Kuantitas menyangkut jumlah sumber daya manusia yang umumnya dianggap kurang penting kontribusinya terhadap pembangunan masyarakat, dibandingkan aspek kualitas. Bahkan kuantitas SDM tanpa disertai kualitas yang baik, akan menjadi beban pembangunan pesantren itu sendiri. Sedangkan kualitas yang menyangkut mutu sumber daya manusia, yang berkaitan dengan kemampuan, baik 
kualitas fisik maupun kualitas non fisik (kecerdasan dan mental). Karena itu, untuk kepentingan pembangunan pesantren dalam hal sumberdaya manusia, maka perlu kualitas SDM yang lebih bemutu sebagai prasyarat mutunya pesantren.

Aspek yang dikembangkan dalam menyelaraskan dengan tujuan pendidikan nasional yang ada di undang undang tersebut serta memaksimalkan peranserta oraganisasi kependidikan yang ada di pondok pesantren, maka perlu adanya langkah-langkah yang representatif. Untuk itu Pondok pesantren membangun fondasi keilmuan melalui beberapa hal yang secara substansial dibutuhkan perhatian yanag lebih diutamakan diantaranya adalah : (Pertama) Pemberdayaan Sumber daya Santri (peserta didik) melalui manajemen sumberdaya Santri, karena santri merupakan konsumen awal dari sebuah program pendidikan, perlu adanya desain perencana, pelaksana, penilai dan memberikan arah bagi tindak lanjut program yang dikembangkan oleh pondok pesantren, (Kedua) Membangun budaya organisasi yang sehat yaitu munculkanya nilai-nilai kesadaran akan bekerja sama dengan kelompok dan membangun norma yang dapat menjamin kualitas kinerja lembaga pesantren terkait serta (Ketiga) life skill, keterampilan hidup yaitu tingkat keberhasilan pesantren dalam mengembangkan visi dan misinya melalui pengembangan tenaga keterampilan sebagai jawaban atas tuntutan dan kebutuhan santri pada masa mendatang. Keberhasilan pesantren dalam mengembangkan visi dan misinya tidak terlepas dari pandangan akan tingkat religiusitas dari lulusannya, sehingga penilaian seperti ini akan senantiasa melekat pada diri santri sebagai sosok yang dihasilkan oleh pesantren guna mengembangkan, menjaga dan melestarikan nilai-nilai ajaran agama Islam dalam kehidupan keseharian.
Hal ini sesuai dengan apa yang di ungkapkan oleh (Mastuki, 2010 : 1) Menurutnya, Pesantren adalah lembaga pendidikan tradisional islam untuk mepelajari, memahami, menghayati dan mengamalkan ajaran agama islam dengan menekankan pentingnya moral keagamaan sebagai pedoman perilaku sehari-hari. Mengkaji tentang posisi dan eksisitensi pondok pesantren sangat menarik, pada sisi lain pondok pesantren harus mengakui adanya problema eksnternal berupa kelemahan yang dialaminya, yaitu pandangan miring dan kesan negatif terhadap lembaga pondok pesantren.

Pesantren sebagai lembaga kader lebih mementingkan pendidikan dibanding pengajaran. Pendidikan dalam Pesantren adalah upaya pengembangan sumber daya manusia secara keseluruhan dan maksimal baik akal, jiwa maupun badan dalam totalitas kehidupan asrama selama dua puluh empat jam dengan berbagai macam disiplinnya dan konsekuensi terhadap pelanggaran disiplin tersebut. Dari pendidikan dan pengawasan yang kontinu dan baik tersebut, diharapkan lahir sumber daya manusia yang baik.

Pondok pesantren yang baik dan maju tidak lepas dari input yang didapat. Input yang didapat harus berdasarkan criteria-kriteria yang diinginkan agar tujuan pondok pesantren dapat terlaksanan dengan maksimal dan berdasarkan visi dan misi pondok pesantren. Untuk menggapai input yang terbaik perlu adanya polarisasi dan desain yang mapan dalam system manajemennya, terutama manajemen sumberdaya santri. Manajemen sumberdaya santri merupakan bagian ikhtiar pondok pesantren untuk mencari input-input santri yang ingin maju dan terarah sesuai dengan visi dan misi pondok pesantren. Kegiatan manajemen sumberdaya santri hanya berkecimpung kedalam beberapa hal diantaranya adalah kegiatan perencanaan 
sumberdaya santri, membuat sistim rekrutmen dan seleksi yang sesuai dengan pondok pesantren, menciptakan pola orientasi dan menempatan yang nyaman bagi santri, dan system evaluasi yang berkala agar evaluasi ini sebagai bagaian dari motivasi untuk membentuk dan membangun budaya organisasi di pondok pesantren lebih up to date. Dan mampu bersaing dengan kemajuan teknologi dan komunikasi yang semakin menjamur di dunia global. Penelitian terfokus pada 4 pertanyaan penelitian tuk itu dalam penelitian ini terfokus kepada empat hal yaitu 1. Bagaimana desain perencanaan sumberdaya Santri Pondok Pesantren Bairul Arqom Balung?. 2. Bagaimana sistem rekrutmen dan seleksi sumberdaya Santri Pondok Pesantren Bairul Arqom Balung?. 3. Bagaimana proses orientasi dan penempatan sumberdaya Santri Pondok Pesantren Bairul Arqom Balung?, dan 4. Bagaimana evaluasi sumberdaya Santri Pondok Pesantren Bairul Arqom Balung?.

\section{METODE PENELITIAN;}

Penelitian ini merupakan penelitian deskriptif dengan menggunakan pendekatan kualitatif. Definisi metode kulaitatif Menurut Bogdan dan Taylor, yang dikutip oleh (Moleong, 2008 : 4) Metode kualitatif sebagai prosedur penelitian yang menghasilkan data deskriptif berupa kata-kata tertulis atau lisan dari orang-orang dan prilaku yang dapat diamati.

Data diperoleh melalui pengamatan, dimana peneliti berfungsi sebagai instrumen untuk melakukan observasi, pengamatan terkait prosesatau kejadian kejadian yang terkait dengan focus penelitian, wawancara mendalam dengan informan, mencari data dengan bertanya kepada beberapa orang yang dianggap penting dan mewakili informasi terkait dengan focus penelitian dan menggunakan studi dokumentasi. dokumen burapa berkas-berkas yang berasal dari arsip pondok pesantren atau foto kegiatan yang perlah dilakukan terkait dengan focus penelitian ini

Menurut (Moleong, 2008 : 147) Tekhnik analisis data yang digunakan dalam penelitian ini adalah menggunakan tekhnik analisis data kualitatif deskriptif (berupa kata-kata bukan angka). Data dianalisis dengan analisis interaktif melalui 3 kegiatan yaitu reduksi data, penyajian data dan penarikan kesimpulan.

Keabsahan data diperoleh dengan kredibilitas yaitu perpanjangan pengamatan, melakukan pengamatan secara terus menerus dan triangulasi sumber dan metode.

\section{HASIL PENELITIAN DAN PEMBAHASAN}

Berdasarkan hasil wawancara dan beberapa studi dokumentasi bahwa penelitian Manajemen Sumberdaya Santri yang dilakukan peneliti mengahasilkan beberapa hasil paparan data.

Data yang peneliti peroleh terkait dengan santri diantanya adalah jumlah santri. Santri yang belajar di pondok pesantren baitul arqom ini dibagi dua tingkatan, karena pondok pesantren baitul arqom adalah pesantren muadalah yang setingkat dengan Mts dan MA. Lulusan pondok pesantren baitul arqom bisa langsung melanjutkan sekolah kejenjang selanjutnya setingkaat perguruan tinggi swasta ataupun negeri bahkan ada yang mampu melanjutkan di perguruan tinggi di luar negeri. Tingkatan pertama adalah santri yang setingkat dengan Tsanawiyah memiliki jumlah santri total 204 orang. Sedangkan tingkatan yang kedua adalah setingkat aliyah dengan jumlah santri keseluruhan adalah 205 orang. Jadi total santri keseluruhan pondok pesantren baitul arqom antra laki laki dan 
perempuan, antara kelas 1 saampai kelas 6 tabel dibawah ini : adalah 409 orang dengan rincian pada

Tabel 1,

Jumlah Santri Setingkat Tsanawiyah

\begin{tabular}{|c|c|c|c|c|c|c|c|c|c|c|c|}
\hline \multicolumn{2}{|c|}{ Kelas I } & Jumlah & \multicolumn{2}{|c|}{ Kelas II } & Jumlah & \multicolumn{2}{|c|}{$\begin{array}{l}\text { Kelas } \\
\text { III }\end{array}$} & Jumlah & \multicolumn{2}{|c|}{$\begin{array}{c}\text { Kelas I, II dan } \\
\text { III }\end{array}$} & Jumlah \\
\hline $\mathrm{L}$ & $\mathrm{P}$ & \multirow{2}{*}{82} & $\mathrm{~L}$ & $\mathrm{P}$ & \multirow{2}{*}{65} & $\mathrm{~L}$ & $\mathrm{P}$ & \multirow{2}{*}{57} & $\mathrm{~L}$ & $\mathrm{P}$ & \multirow{2}{*}{204} \\
\hline 30 & 52 & & 28 & 37 & & 22 & 35 & & 80 & 124 & \\
\hline
\end{tabular}

Tabel 2,

Jumlah Santri Setingkat 'Aliyah

\begin{tabular}{|c|c|c|c|c|c|c|c|c|c|c|c|}
\hline \multicolumn{2}{|c|}{ Kelas I } & $\begin{array}{c}\text { Jumla } \\
h\end{array}$ & \multicolumn{2}{|c|}{ Kelas II } & $\underset{h}{\text { Jumla }}$ & \multicolumn{2}{|c|}{$\begin{array}{c}\text { Kelas } \\
\text { III }\end{array}$} & $\underset{h}{\text { Jumla }}$ & \multicolumn{2}{|c|}{ Kelas I, II dan III } & $\begin{array}{c}\text { Jumla } \\
h\end{array}$ \\
\hline $\mathrm{L}$ & $P$ & \multirow{2}{*}{87} & $\mathrm{~L}$ & $\mathrm{P}$ & \multirow{2}{*}{55} & $\mathrm{~L}$ & $\mathrm{P}$ & \multirow{2}{*}{72} & $\mathrm{~L}$ & $\mathrm{P}$ & \multirow{2}{*}{205} \\
\hline 35 & 52 & & 22 & 23 & & 21 & 52 & & 78 & 127 & \\
\hline
\end{tabular}

Data selanjutnya adalah data wawancara dengan informan, data ini adalah hasil wawancara peneliti dengan informan mengenai manajemen sumberdaya santri. :

Sebelum merekrut santri baru di baitul arqom yang perlu dilakukan lembaga adalah dengan cara rapat koordinasi resmi maupun tidak resmi seperti hasil wawancara dengan informan berikut ini :

"hal yang perlu dilakukan ketika memenuhi kebutuhan santri tahun ajaran baru diantranya adalah dengan Rapat baik resmi, maupun sekedar obrolan / tidak resmi yang dilakukan diantranya pembentukan panitian pendaftaran santri bar yang semuanya di kerjakan oleh organisasi santri yang ada di baitul arqom. Direktur dan Pembina santri hanya memfasilitasi dan memberikan saran saran strategis agar panitian pendaftaran dapat berjalan dengan baik dan dapat mengakomodir kebutuhan panitia."

Rapat koordinasi dibutuhkan untuk melakukan perencanaan pengkoordinasian santri baru yang akan masuk ke pondok pesantren baitul arqom seperti yang disampaikan informan dalam wawancara kita:

"rapat koordinasi diperlukan sebagai bagian dari kerja apa saja yang dilakukan oleh panitian pendaftaran santri baru seperti menyiapkan tanggal pelaksanaan pendaftara, menggunakan berapa gelombang untuk pendaftaran santri baru, menyiapkan formulir dan siapa saja yang menjaga di stan pendaftaran ketika pendaftaran telah dibuka serta menyiapkan ujian kompetensi dalam perekrutan sebagai kebutuhan PP pesantren ingin mengetahui kemampuan yang dimiliki santri baru".

Informasi terkait Pondok Pesantren Baitul Arqom Balung di peroleh melalui beberapa cara diantranya adalah melalui selebaran berupa brosur, kalender yang disebarkan kepada santri yang masih aktif di pondok pesantren, website dan media social resmi pondok pesantren baitul arqom seperti yang disampaikan informan kepada peneliti :

"PP Baitul arqom tidak melakukan promosi berlebihan seperti mendatangi sekolah sekolah atau membuat bener ditempatkan ditempat strategis di daerah daerah atau jalan jalan yang sering 
dilakukan leh lembaga lain. Mengenai informasi terkait PP Baitul arqom calon santri memperoleh dari Alumni (santri yang pernah belajar di PP Baitul arqom), tokoh masyarakat yang sering berkomunikasi dengan PP Baitul arqom, brosur sebagai pengingat atau informasi pendaftara, kalender yang dibawa pulang oleh santri, dan web atau sososial media PP Baitul arqom."

Perencanaan sumberdaya manusia atau Human resources plenning disingkat PSDM merupakan fungsi pertama dan utama dari Manajemen sumberdaya manusia, dalam hal ini Baitul Arqom dalam merekrut santri baru membentuk panitia pendaftaran santri baru yang dilakukan oleh organisasi santri baitul arqom. Seperti yang di informasikan oleh informan kepada peneliti :

"Tidak sepenuhnya menggunakan perencanaan yang ada di teori, hanya saja terkait kebutuhan akan santri baru, $P P$ Baitul arqom menyusun panitian pendaftaran santri baru karena PP Baitul arqom yakin tiap tahunnya pasti ada yang mendaftar sebagai santri baru di PP Baitul arqom"

Metode nonilmiah diartikan bahwa perencanaan SDM hanya didasarkan atas pengalaman, imajinasi, dan perkiraanperkiraan dari perencanaannya saja. Metode ilmiah diartikan bahwa bahwa perencanaan SDM dilakukan berdasarkan atas hasil analisis dari data, informasi, dan peramalan-peramalan (forecasting) dari perencanaannya. P.P baitul arqom dalam merencanakan menggunakan metode non ilmiah dan metode ilmiah karena perlu untuk menganalisis meskipun tidak secara sempurna, seperti yang di informasikan kepada peneliti :

"dalam hal ini PP Baitul arqom dalam memenuhi kebutuhan santri baru berdasarkan Pengalaman yang pernah terjadi di PP Baitul arqom serta beberapa pengalaman dari pondok pesantren gontor, analisis data dilakukan sebagai bagian dari mencari atau mendapatkan gambaran terkait santri baru yang akan memasuki PP Baitul arqom, informasi di butuhkan sebagai bagian pemenuhan kebutuhan".

Recruitment adalah mencari dan mendapatkan pelamar berkualitas bagi perusahaan untuk mengisi jabatan yang kosong. P.P baitul arqom menerima semua santri yang ingin belajar di pondok pesantren. Tidak ada seleksi yang dilakukan. Tes ada tapi bukan sebagai bagian dari seleksi atau menyingkirkan santri. Akan tetapi sebagai mengetahui kompetensi yang dimiliki calon santri baru. Seperti yang di informasikan kepada peneliti :

"No seleksi. Artinya PP Baitul arqom tidak menolah santri yang akan mondok di PP Baitul arqom. Rekrutmen mungkin nama lainnya adalah pendaftaran santri baru”

Proses pengkrekrutan santri baru di baitul arqom yaitu calon santri baru datang ke tempat pendaftaran santri baru yang di sediakan oleh panitia, calon santri baru mengisi formulir dan melengkapi persyaratan yang dibutuhkan oleh pondok pesantren. Hal ini yang disampaikan informan kepada peneliti :

"Prosesnya hanya singkat, santri yang ingin mondok di PP Baitul arqom datang ke pondok menemui panitian pendaftaran atau menemui kyai atau menemui ustad, kalau menemui kyai atau ustad pasti disarankan untuk menemui panitian pendaftaran untuk di data terkait identitas dan beberapa persyaratan yang harus dibawa. kemudian melakukan pendaftaran untuk menjadi santri baru kepada panitian pendaftaran santri baru”.

Dalam teori rekrutmen ada istilah Strategi Rekrutmen, dimana kegiatannya adalah Kebutuhan karyawan, Surat permintaaan karyawan baru, Rasio hasil, Analisi pekerjaan, Deskripsi pekerjaan, Spesifikasi pekerjaan. Pondok pesantren baitul arqom dalam merekrut santri tidak 
ada strategi khusus, hanya saja jika pendaftaran santri baru akan dimulai atau di mulai PP baitul arqom akan menginformasikan kepada masyarakat, melalui website, melalui baleho didepan pondok atau melalui alumni serta ustad yang ada di pondok seperti yang di informasikan kepada peneliti :

"Tidak ada strategi khusu yang dilakukan. Mungkin yang menyerempet meyerempet kepada strategi tersebut adalah bahwa PP Baitul arqom menginformasikan kepada masyarakat yang ingin mendaftarakan anaknya ke PP Baitul arqom yaitu hari dan tanggal pendaftaran santri baru"

Pondok pesantren baitul arqom tidak ada seleksi yang dilakukan artinya pondok pesantren baitul arqom menerima seluruh santri yang ingin belajar di pondok. Seperti yang di informasikan informal kepada peneliti:

"Pondok Pesantren Baitul Arqom tidak menolah santri yang akan belajar di PP Baitul arqom, semuanya diterima dengan syarat mematuhi peraturan yang berlaku di PP Baitul arqom jadi PP Baitul arqom menerima semua yang ingin menjadi santri"

Santri yang belajar di pondok pesantren berasal dari berbagai daerah, ada yang dari Kalimantan, sumatera, ambon, bali ada pula yang dari jawa dan sekitar balung. Artinya santri yang masuk ke pondok berasal dari ekstrenal pondok pesantri hal ini yang disampaikan oleh informan kepada peneliti :

"untuk santri yang akan masuk ke PP Baitul arqom kebanyakan dari luar PP Baitul arqom mungkin itu yang dapat menjawab sumber rekrutmen dari eksternal PP Baitul arqom. Kalau untuk merekrut ustad atau asatid bisa dari luar maupun dari pihak dalam PP Baitul arqom."

Tidak ada penyaring santri yang dilakukan pondok pesantren, santri akan masuk di baitul arqom akan diterima semua jika memenuhi syarat minimal lulus dari SD atau MI. seperti yang disampaikan informan kepada peneliti :

"tidak ada penyaringan santri yang dilakukan PP Baitul arqom, mungkin seleksi yang dilakukan hanya sebatas seleksi administrasi ya kalau tidak memiliki ijasa SD harus sekolah SD terlebih dahulu. kalau terkait ujian masuk atau tes yang diberikan kepada santri baru merupakan upaya PP Baitul arqom untuk mengetahui kemampuan diri setiap santri baru yang menjadi bagian dari PP Baitul arqom."

Untuk menjadi santri baitul arqom minimal memiliki beberapa syarat yang perlu di lengkapi diantaranya ijasah SD atau MI, KK, identitas yang jelas untuk di daftarkan PD Pontren Kemenag. Seperti yang di informasikan kepada peneliti :

"persyaratannya adalah hal hal yang menjadi persyaratan untuk didaftarkan ke PD Pontren atau Persayaratan Pesantren Muadalah diantaranya Tamat SD atau SMP atau MTS dan memiliki ijasahnya, KK , Pas foto, dan sehat jasmani dan rohani. Memilii keinginan untuk belajar"

Tidak ada proses seleksi yang ketat, akan tetapi kalau dikatakan adan mungkin seleksi yang bersifat administrasi. Seperti yang di informasikan kepada peneliti :

"mungkin seleksinya adalah seleksi administrasi melalui ijazah atau SK Lulus kalau yang belum memiliki ijasah, Sk sehat dari kesehatan “

Setelah santri terdaftar di pondok pesantren baitul arqom hal apa yang dilakukan oleh baitul arqom melakukan penempatan dan pengenalan tentang pondok pesantren baitul arqom. Seperti yang ddisampaikan kepada peneliti :

"setelah melakukan tahap pendafatran lalu dilakukan tes atau ujian untuk mengetahui kemampuan santri baru. Tahapan selanjutnya adalah penempatan. Santri di tempatkan berdasarkan asal daerah atau orang yang dikenalnya tujuannya adalah agar santri baru dapat 
beradaptasi dan mendapatkan kenyamanan. Kalau sudah kerasan atau mampu beradaptasi dengan lingkungan pondok, maka santri akan ditempatkan sesuai dengan kemampuang yang dimilikinya."

Orientasi yang dilakukan pondok pesantren baitul arqom berupa pekan penganalan dan khutbatul arsy sebelum itu ada sedikit pengenalan olah raga untuk di ketahui oleh santri baru yang baru menempati pondok pesantren baitul arqom. Hal ini yang disampaikan onforman kepada peneliti:

"Iya, Ada Orientasi. Orientasi secara formal bernama khutbatul arsy dan pecan pengenalan. Program ini dilakukan bagian dari orientasi santri baru yang berada di pondok pesantren baitul arqom"

Tujuan orientasi yang dilakukan pondok pesantren baitul arqom tidak lain adalah untuk mengenalakan kepada santri iklim pembelajaran yang ada didalam pondok pesantren. Hal ini yang disampaikan oleh informan kepada peneliti:

"orientasi dilakukan untuk santri baru yang berada di PP Baitul arqom dapat beradaptasi mampu untuk mengenali lingkungan dan kultur budaya di PP Baitul arqom dan dapat penyesuaian diri bagaimana cara hidup dipondok."

Orientasi santri baru yang bersifat formal dilakukan pada awal tahun ajaran baru. Seperti yang di kemukakan oleh informan kepada peneliti:

"Orientasi secara formal atau resmi dilakukan setiap Di awal tahun ajaran baru dengan program khutbatul arsy dan pengenalan ke pondokan kepada santri baru."

Tipe orientasi, terdapat dua tipe orientasi yang dapat diterapkan oleh perusahaan atau organisasi, yaitu : induksi dan sosialisasi. Pondok pesantren baitul arqom menerapkan dua tipe tersebut. Yang pertama dilakukan secara tidak formal artinya santri baru mencari tahun sendiri terkait pondok pesantren kepada santri senior atau ustad yang ada dipondok. Yang kedua dilakukan secara formal seperti khutbatul Arsy di aula pondok pesantren. Hal ini yang disampaikan oleh informan kepada peneliti :

"PP Baitul arqom melakukan orientasi dengan cara induksi, artinya di pondok pesantren baitul arqom santri boleh melakukan pengenalan langsung atau bertanya kepada senior, atau ustad terkait kepondokan, ada apa saja yadi pondok pesantren baitul arqom. dan sosialisasi artinya pihak pondok memberikan pengarahan dan pemaparan secara formal kepada santri baru terkait pondok pesantren baitul arqom."

Cara penilaian yang dilakukan pondok pesantren baitul arqom yaitu dengan cara ujian dan beberapa pengamatan kepada santri. Hal ini yang disampaikan kepada peneliti :

"santri baitul arqom dalam penilaiannya dilakukan dengan beberapa hal, diantaranya Melalui ujian yang dilakukan oleh pondok pesantren dan melalui pengamatan selama berada di pondok pesantren."

Penilaian santri dilakukan tidak ada lain hanya untuk mengetahui seberapa besar daya serap santri dan sebagai bahan evaluasi pendidikan yang ada di pondok pesantren. Hal ini yang disampaikan oleh informan kepada peneliti:

"Penilaian ini dilakukan Untuk mengetahui seperapa besar daya serap pembelajaran diterima oleh santri, juga penilaian ini dilkukan untuk mengevaluasi proses pendidikan. Setelah dilakukan penilaian maka akan di pelaporan kepada stekhorlder terkait untuk menjadi bahan instropeksi santri itu sendiri serta lembaga pondok pesantren baitul arqom."

Elemen elemen dalam system penilaian di baitul arqom melibatkan seluruh stekholder, mulai dari guru 
(ustad), wali kelas, pengasuh santri dan pembimbing santri. Hal ini yang disampaikan kepada peneliti :

"Elemen yang menilai santri bukan hanya guru/ustad. Semua elemen ikut menilai santri yang bersangkutan mulai dari Guru,Wali Kelas,Pengasuhan Santri, dan pembimbing santri. Hal ini dilakukan agar penilaian lebih objektif dan tidak memihak."

Pendekatan untuk menilai santri yang dilakukan pondok pesantren baitul arqom adalah pendekatan akademis dan humanis. Pendekatan ini dilakukan sebagai bagian kerangka pendidikan yang di terapkan oleh pondok pesantren baitul arqom. Hal ini yang disampaikan informan kepada peneliti :

"Pendekatan dalam menilai santri adalah pendekatan Akademis dan humanis. Akademis artinya dari sector pembelajaran yang ada di kelas dan hal hal yang bersifat akademis semua dinilai. Humanis artinya perilaku setiap hari dinilai selanyaknya mendidik dan tidak membuat kerusuhan di pondok."

Metode penilaian santri yang dilakukan pondok pesantren baitul arqom balung ini adalah dengan ujian Lisan, Ujian Tulis dan Pengamatan kepada santri ketika berproses di pondok pesantren baitul arqom. Hal ini yang disampaikan oleh informan kepada peneliti:

"Metode penilaian yang dilakukan pondok pesantren baitul arqom adalah dengan ujian Ujian Lisan, ujian Tulis dan pengamatan terkait dengan perilaku selam di pondok pesantren".

Proses penilaian santri baitul arqom tidak hanya dilakukan pada pertengahan semester dan akhir semester saja seperti yang dilkukan sekolah formal selama ini. Proses penilain santri di pondok pesantren melibatkan beberapa stekholder yang terkait saat proses pembelajaran di pondok pesantren bukan hanya akademis saja, penilaian terkait akhlak dan kepribadian santri juga penting untuk di nilai. Hal ini yang disampaikan informan kepada peneliti :

"Santri dinilai bukan hanya dinilai dari segi akademis akan tetapi yang lebih penting adalah penilaian Akhlak \& Kepribadian Santri melalui setiap ujian awal / akhir semester, pengamatan setiap saat oleh wali kelas, pembimbing kamar dan pengasuh."

\section{PEMBAHASAN}

Pembahasan mengenai Manajemen Sumberdaya Santri di Pondok Pesantren Baitul Arqom Balung, dalam hal ini akan dijelakan dari 4 fokus penelitian yang menjadi kajian di penelitian ini. Penjelasan tersebut meliputi :

\section{Desain perencanaan sumberdaya Santri Pondok Pesantren Bairul Arqom Balung. \\ Berdasarkan temuan-temuan hasil} wawancara dan beberapa dokumentasi penelitian ini, maka hasilnya sebagai berikut : 1) Perencanaan sumber daya santri di pondok pesantren baitul arqom dilakukan berdasarkan analisis kekosong santri dari kelas 1 ketika santri lama sudah naik kelas 2. 2) Menyusun perencanaan sumberdaya santri yaitu dengan cara rapat koordinasi baik formal maupun nonformal untuk menentukan kapan terlaksananya pendaftaran masuk santri baru di pondok pesantren dan pembentukan panitian pendaftaran. 3) Melakukan analisis data terkait sumber-sumber internal maupun eksternal, mengecek informasi, serta memikirkan perkiraan-perkiraan berdasarkan pengalaman yang pernah dilakukan. 4) Pelaksanaan program perencanaan sumber daya santri terkait dengan kebijakan untuk merekrut santri baru yang dilakukan oleh pihak pondok pesantren. 


\section{Gambar 1}

Analisi perencanaan Sumberdaya santri

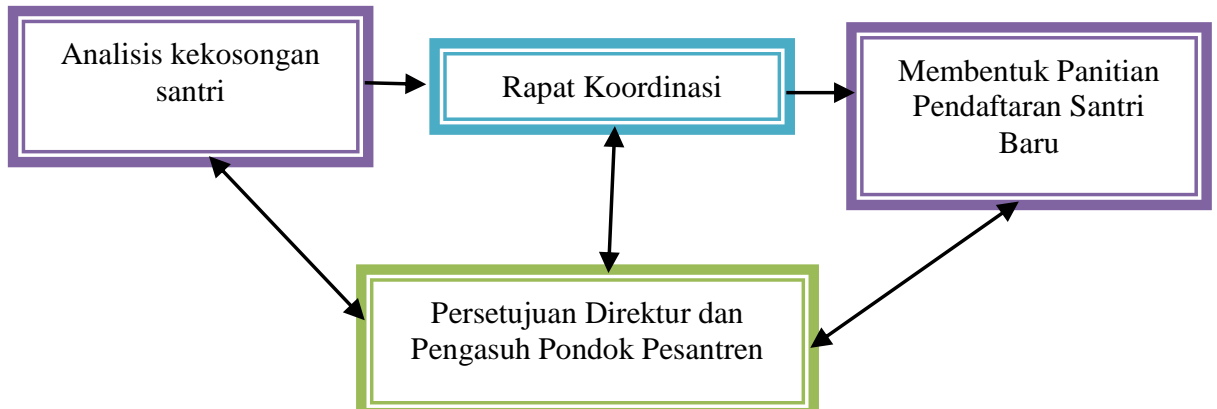

Dalam konteks manajemen sumber daya manusia dalam hal ini adalah santri, pondok pesentren perlu memikirkan langkah langkah mencari kekosongan setelah ditinggalkan. Karena santri yang ada di pondok pesantren akan mengalami kelulusan dan keluar dari pondok pesantren, sehingga mengakibatkan kekosongan di tingkat bawah atau dikelas terendah. Menurut (Sondang, 2008 : 41) perencanaan merupakan proses penentuan kebutuhan sumber daya manusia pada masa yang akan datang berdasarkan perubahan-perubahan yang terjadi dan persediaan tenaga yang ada di pesantren. apabila berbicara tentang perencanaan sumberdaya manusia, yang menjadi fokus perhatian ialah langkah-langkah yang diambil oleh manajemen guna lebih menjamin bahwa bagi organisasi tersedia tenaga kerja yang tepat untuk menduduki berbagai kedudukan, jabatan dan pekerjaan yang tepat pada waktu yang tepat, kesemuanya dalam rangka mencapai tujuan dan berbagai sasaran yang telah dan akan ditetapkan.

Melihat hasil temuan dan paparan data peneliti terkait perencanaan sumber daya santri seperti tersebut diatas secara garis besar sesuai dengan pendapat (Meldona, 2009 96) yang mengatakan bahwa : proses perencanaan tenaga kerja dilakukan melalui beberapa tahapan sesuai dengan model perencanaan yang dimiliki. Secara sederhana proses perencanaan tenaga kerja berkaitan dengan empat aspek, yaitu 1. Prediksi/peramalan jumlah karyawan yang dibutuhkan (forecast of employees). 2. Identifikasi sumber daya manusia yang tersedia dalam organisasi (inventori sumber daya manusia). 3. Analisis keseimbangan penawaran dan permintaan sumber daya manusia. 4 . Program aksi.

Meskipun pendapat meldona tersebut dipaparan secara sempurna bahkan baik untuk pondok pesantren, akan tetapi tidak seluruhnya dianut oleh pondok pesantren Baitul Arqom Balung dan ada istilah-istilah yang berbeda dalam proses perencanaan sumberdaya santri di pondok pesantren atau secara tidak sengaja dilakukan, akan tetapi tidak ditulis secara administrasi berupa dokumentasi penting.

Analisis foktor penyebab perubahan jumlah santri di pondok pesantren Baitul Arqom Balung terjadi berdasarkan siklus tahunan yang terjadi secara konsisten. Adaa santri yang keluar, ada santri yang akan memasuki pondok pesantren atau ada santri yang pindah atau ada santri yang mengundurkan diri. Untuk itu pondok pesantren harus mengetahui apakah jumlah santri telah mengalami perubahan. Sesuai apa yang disampaikan Meldona, bahwa perubahan - perubahan tenaga manusia dalam organisasi sebagai sesuatu yang alami dan yang akan terjadi, seperti kebutuhan tenaga baru sebagai akibat adanya anggota yang keluar, mengundurkan diri atau mengabdikan diri kepada masyarakat 
dirumahnya masing-masing, meninggal dunia dan lain-lain.

Setelah pondok pesantren Baitul Arqom Balung menganalisis berbagai faktor yang mempengaruhi atau menyebabkan perubahan kebutuhan sumber daya manusia dilingkungannya. Maka langkah selanjutnya adalah menyusun perencanaan untuk menentukan kebutuhan atas tenaga apa saja dan apa juga kriteria yang diperlukan oleh calon santri yang nantinya akan direkrut. Sehingga dilakukannya rapat koordinasi untuk melakukan langkah langkah strategi dalam perengkrutan sumberdaya santri ini. Diantaranya adalah membentuk panitian pendaftaran santri baru di lingkungan pondok pesantren Baitul Arqom Balung, serta menentukan apa saya yang perlu di persiapan seperti peralatan administrasi serta fasilitas yang akan diberikan kepada calon santri baru.

Upaya perencanaan yang dilakukan oleh pondok pesantren Baitul Arqom terhadap kebutuhan santri, menurut peneliti memiliki beberapa sisi positif, Pertama, pondok pesantren Baitul Arqom Balung, memiliki analysis yang kuat dalam hal memberikan informasi tentang kebutuhan Santri, persyaratan Santri, perilaku Santri, dan Sarana prasarana yang dipergunakan, memiliki job description yang sesuai dalam hal pembagian tugas, dan job evaluation apabila ada kesalahan atau pelanggaran yang dilakukan, tindakannya keras dan mendidik. Kedua, perencanaan sumber daya santri pesantren Baitul Arqom selalu diadakan koordinasi. Ketiga, dari perencanaan sumber daya santri yang telah disusun itu dipastikan pondok pesantren Baitul Arqom tidak akan menolak semua santri yang akan belajar di pondok pesantren, mereka semua akan dibina dan dididik sesuai dengan peraturan Baitul Arqom.

\section{Sistem rekrutmen dan seleksi sumberdaya Santri Pondok Pesantren Bairul Arqom Balung.}

Berdasarkan paparan data temuantemuan penelitian yang berkaitan dengan rekruitmen dan seleksi Sumber Daya santri di pondok pesantren Baitul Arqom Balung adalah : 1) Ada satu pola rekrutmen yang ada di pondok pesantren Baitul Arqom Balung, yaitu perekrutan eksternal pesantren (masyarakat luar pesantren). 2) Menentukan proses rekrutmen dalam hal ini pola pendaftaran/ alur pendaftaran santri baru. 3) Menentukan persyaratan masuk pondok pesantren. 4) Dalam proses rekrutmen santri dilakukan secara humanis. 5). Hanya Seleksi administrasi yang dilakukan di pondok pesantren baitul arqom 6) Tidak Menggunakan sistem gugur dalam proses seleksi, santri baru di tes atau di uji untuk mengetahui kualitas santri baru.

Rekrutmen menjadi salah satu kegiatan yang sangat penting dalam manajemen sumber daya manusia sebab sebagai awal dari kegiatan yang dilakukan organisasi pesantren untuk mendapatkan tenaga yang tepat untuk mengisi anggota yang kosong dan kekurangan. Proses rekrutmen dan seleksi Sumberdaya santri di pondok pesantren Baitul Arqom Balung terjadi secara terus menerus setiap tahunnya, artinya setiap tahun terdapat siklus kekosongan santri yang terjadi pada lembaga pondok pesantren baitul arqom. Untuk itulah diperlukan pola rekrutmen yang baik untuk menciptakan anggota yang memiliki daya saing tinggi, etos belajar tinggi, semangat belajar yang tinggi.

Rekrutmen adalah mencari dan mendapatkan santri berkualitas dari berbagai daerah untuk mengisi peran dari lembaga pendidikan yang kosong. P.P baitul arqom menerima semua santri yang ingin belajar di pondok pesantren. Tidak ada seleksi yang dilakukan. Tes atau ujian 
untuk calon santri baru diadakan sebagai bagian untuk mengetahui kompetensi yang dimiliki calon santri baru, serta lembaga bisa mengetahuan dimana santri baru tersebut di tempatkan.

Pola rekrutmen sumberdaya santri baru baitul arqom balung adalah pola ekternal. Santri yang belajar di pondok pesantren berasal dari berbagai daerah, ada yang dari Kalimantan, Sumatra, Ambon, Bali ada pula yang dari jawa dan sekitar balung. Artinya santri yang masuk ke pondok berasal dari ekstrenal pondok pesantri. Menurut (Jusmaliana, 2011: 80) rekrutmen eksternal berarti mencari calon karyawan (santri) dari luar perusahaan (luar pondok pesantren). sumber eksternal yang terdiri atas orang- orang yang belum menjadi santri atau di luar pesantren dan akan direkrut, dalam proses rekrutmen ini pondok pesantren Baitul Arqom berupaya untuk menerapkan prinsip Humanis, artinya pesantren memberikan kesempatan secara terbuka kepada para calon santri yang memiliki kemampuan atau kompetensi bahkan tidak memiliki kompetensi di bidang agama untuk masuk atau mendaftar menjadi santri di pondok pesantren baitul arqom.

Proses pengrekrutan santri baru di baitul arqom yaitu calon santri baru datang ke tempat pendaftaran santri baru yang di sediakan oleh panitia, calon santri baru mengisi formulir dan melengkapi persyaratan yang dibutuhkan oleh pondok pesantren. Tidak ada penyaring santri yang dilakukan pondok pesantren, santri akan masuk di baitul arqom akan diterima semua jika memenuhi syarat minimal lulus dari SD atau MI. Untuk menjadi santri baitul arqom minimal memiliki beberapa syarat yang perlu di lengkapi diantaranya ijasah SD atau MI, KK, identitas yang jelas untuk di daftarkan PD Pontren Kemenag. Persyaratannya adalah hal hal yang menjadi persyaratan untuk didaftarkan ke PD Pontren atau Persayaratan Pesantren Muadalah diantaranya Tamat SD atau SMP atau MTS dan memiliki ijasahnya, KK, Pas foto, dan sehat jasmani dan rohani. Memilii keinginan untuk belajar.

Sesuai dengan pendapat (Maldona, 2009 : 147) sumber eksternal, yaitu rekrutmen yang berasal dari luar pesantren. terdiri atas manusia yang ingin melamar menjadi tenaga pendidik. Sedangkan metodenya mengunakan open house, merupakan model penarikan yang relatif baru, yaitu dengan cara mengundang orang di sekitar perusahaan atau sekitar pesantren untuk mengunjungi dan melihat keadaan pesantren, memperoleh penjelasan untuk mengenal lembaga tersebut.

Dari analisis diatas dapat dilihat bahwa metode rekrutmen yang dilaksanakan oleh pondok pesantren Baitul Arqom terdapat kesamaan dengan pendapat (meldona, 2009 : 135) tentang proses yang harus diperhatikan dalam merekrut Sumberdaya Santri Baru untuk pondok pesantren, yaitu dengan cara: a) Penentuan keanggotaan yang kosong (strategi rekrutmen), b) Penentuan persyaratan jabatan (perencanaan rekrutmen), dan c) Penentuan sumber dan metode rekrutmen.

Menurut (Sondang, 2008 : 137 ) Langkah-langkah dalam proses seleksi terdiri paling sedikit delapan langkah yang dapat ditempuh, yaitu a. Penerimaan surat lamaran, b. Penyelenggaraan ujian, c. Wawancara seleksi, d. Pengecekan latar belakang pelamar dan surat-surat referensi, e. Evaluasi kesehatan, f. Wawancara oleh atasan, g. Pengenalan pekerjaan, dan h. Keputusan.

Proses seleksi yang dilakukan Pondok pesantren Baitul Arqom tidak sesuai dengan apa yanag di tuturkan oleh sondang dalam buku manajemen sumberdaya manusia. Langkah langkahnya di pondok pesantren baitul arqom adalah 1. Calon santri mendaftarkan diri kepada panitia 
pendaftaran, 2. Mengisi formulir dan menyiapkan persyaratan yang di tentukan oleh pondok pesantren. 3. Mengikuti tes ujian sebagai bagian untuk mengetahui seberapa besar kompetensi yang dimiliki calon santri baru.

Referensi santri senior atau alumni diperlukan untuk lebih mengenal dan mempertajam informasi calon santri baru tersebut. Tujuannya adalah untuk melihat seberapa besar dedikasi dan semangat Belajar yang dimiliki calon santri untuk berproses di pondok pesantren Baitul Arqom Balung.

\section{Proses orientasi dan penempatan sumberdaya Santri Pondok Pesantren Bairul Arqom Balung.}

Berdasarkan temuan penelitian dalam orientasi dan penempatan Santri baru di pesantren Baitul Arqom Balung adalah sebagai berikut: 1). Proses pengenalan atau orientaasi Santri baru terhadap kondisi pondok pesantren dilakukan dengan cara formal dan nonformal. 2). Proses penyampaian orientasi terhadap Santri baru dilakukan dengan cara formal yaitu disebut pengenalan santri baru dan khutbatul arsy. 3).tujuan orientasi di baitul arqom adalah untuk mengenalkan kultur dan pembelajran yang ada di pondok pesantren. 4) Tes awal masuk yang dilakukan sebagai bahan pertimbangan santri baru untuk ditempatkan di kelas dan dikamar mana santri menginap. 5) ada dua tipe orientasi yang dilakukan di pondok pesantren yaitu induksi dan sosisalisi.

$\begin{array}{rrrr}\text { Adanya } & \begin{array}{r}\text { Santri } \\ \text { pondok }\end{array} & \text { baru yang } \\ \text { memasuki } & \text { pesantren }\end{array}$
mengakibatkan pondok pesantren harus memberikan sosialisai dan informasi terkait kelembagaan pondok pesantren baitul arqom, mulai dari system pembelajaran, system kelembagaan, peraturan pondok, ekstrakulrikuler, atau sarana prasarana, dan apa yang harus dilakukan oleh santri baru ketika berada di pondok pesantren baitul arqom. Untuk itulah tantangan bagi lembaga untuk melakukan orientasi dan penempatan sesusai dengan fungsinya masing masing.

Temuan penelitian diatas sesuai dengan pendapat (Maldona, 2009 : 195) bahwa program orientasi sesungguhnya merupakan suatu cara yang penting karena pada dasarnya merupakan usaha dalam membantu pegawai baru (santri baru) untuk mengenali dan memahami tugas- tugas mereka, kondisi organisasi, kebijakan organisasi, rekan sekerja, nilainilai, keyakinan-keyakinan dan lain-lain.

Orientasi menurut (Mondy, 2008 : 227) memiliki kegunaan sebagai berikut : pertama situasi kerja, kalau diartikan kedalam permasalah ini adalah situasi pondok pesantren. Kedua kebijakan dan aturan perusahaan, peraturan yang ada di pondok pesantren baitul arqom. Ketiga kompensasi, santri akan mendapatkaninformasi tterkait imbalan entah itu berupa beasiswa atau yang lain. Manajemen biasanya memberikan informasi ini selama proses rekrutmen dan seleksi serta mengulanginya dalam orientasi. Keempat budaya perusahaan, dapat diartikan sebagai budaya atau iklim pondok pesantren. Kelima kenggotaan Santri, kemampuan dan kemauan seorang Santri baru untuk bekerjasama dalam tim. Keenam pengembangan santri.

Orientasi yang dilakukan pondok pesantren baitul arqom berupa pekan penganalan dan khutbatul arsy sebelum itu ada sedikit pengenalan olah raga (porseni) untuk di ketahui oleh santri baru yang baru menempati pondok pesantren baitul arqom. Pengenal ini meliputi pengenal terkait pondok pesantren, cara belajara di pondok pesantren, organisai santri yang ada di pondok pesantren dan beberapa hal yang berkaitan dengan pondok pesantren. Orientasi santri baru yang bersifat formal dilakukan pada awal tahun ajaran baru.

Tujuan orientasi yang dilakukan pondok pesantren baitul arqom tidak lain adalah untuk mengenalakan kepada santri 
baru iklim pembelajaran yang ada didalam pondok pesantren, serta bakat minat apa yang ingin di kembangkan baik itu berupa ekstra kurikuler maupun kokurikuler. Tipe orientasi, terdapat dua tipe orientasi yang dapat diterapkan oleh perusahaan atau organisasi, yaitu : induksi dan sosialisasi. Pondok pesantren baitul arqom menerapkan dua tipe tersebut. Yang pertama dilakukan secara tidak formal artinya santri baru mencari tahun sendiri terkait pondok pesantren kepada santri senior atau ustad yang ada dipondok. Yang kedua dilakukan secara formal seperti khutbatul Arsy di aula pondok pesantren.

Untuk penempatan santri baru, pondok pesantren betul-betul mempertimbangkan kompetensi dan semngat belajar, serta tingkah laku atau akhlaknya. Penempaatan ini dilakukan secara hati-hati dan penuh dengan perhitungan, artinya santri baru yang akan mendapatkan tempat yang terbaik untuk berproses dalm pembelajran.

\section{Evaluasi sumberdaya Santri Pondok Pesantren Bairul Arqom Balung.}

Dari temuan penelitian dapat diketahui bahwa penilaian pondok pesantren terhadap santri meliputi, 1) dalam menilai santri pondok pesantren menggunakan penilaian akademis dan humanis. 2) penilaian dilakukan dengan beberapa tes, ada tiga tes yang dilakukan pondok pesantren yaitu tes lisan, tes tulis, dan pengamatan setiap hari. 3) semua elemen ikut dalam penilaian yaitu Guru, Wali Kelas, pengasuh santri dan pembimbing santri.

Menurut (Soekarto, 2006 :137) evaluasi adalah proses membuat pertimbangan yang akan dipergunakan sebagai dasar untuk perencanaan, hal ini terdiri dari penerapa tujuan, pengumpulan bukti mengenai pertumbuhan atau kelemahan yang diukur dari tujuan yanag telah di tentukan.
Upaya dalam mengevaluasi sumberdaya Santri di pesantren Baitul Arqom Balung yaitu dengan penilaian akademis dan humanis serta tidak lepas dari perilaku, dan sikap. Pendekatan ini dipakai untuk mengukur seberapa besar peran santri mewujudkan visi misi dalam mencapai tujuan pesantren.

Metode penilaian santri yang dilakukan pondok pesantren baitul arqom balung berupa ujian Lisan, santri langsung berhadapan dengan penguji yang sedang bertugas, dan menanyakaan pertanyaan seputar pelajaran yang sudah diajarkan kepada santri, Ujian Tulis, santri dikumpulkan kedalam satu ruangan dan diberi lembaran soal untuk menjawab semua pertanyaan yang diberikan kepada santri, dan Pengamatan kepada santri ketika berproses di pondok pesantren baitul arqom, pengamatan ini berupa pengamatan sikap, perilaku setiap hari ketika berada di pondok pesantren baitul arqom, apa bila terdapat pelanggaran semua akan tercatat di kantordan nantinya akan diberi tindakan.

Proses penilaian santri baitul arqom tidak hanya dilakukan pada pertengahan semester dan akhir semester saja seperti yang dilkukan sekolah formal selama ini. Proses penilain santri di pondok pesantren melibatkan beberapa stekholder yang terkait saat proses pembelajaran di pondok pesantren bukan hanya akademis saja, penilaian terkait akhlak dan kepribadian santri juga penting untuk di nilai. Semua elemen yang ada di pondok pesantren melakukan evaluasi terhadap santri yang melakukan pembelajaran di pondok pesantren baitul arqom Balung.

Manfaat evaluasi sumberdaya santri menurut (Irham, 2011 : 42) adalah sebagai berikut : 1). Sebagai dasar pengambilan keputusan, 2). Sebagai criteria untuk melakukan validasi tes/menguji keabsahan suatu alat tes, 3). Memberikan umpan balik kepada santri 
sehingga evaluasi dapat berfungsi sebagai wahana pengembangan pribadi.

Hasil evaluasi yang dilakukan oleh pondok pesantren baitul arqom merupakan bagian dari kegiatan untuk mengetahui tingkat kemampuan dan daya serap yang diterima oleh santri. Hasil tersebut sebagai bahan untuk mengabil keputusan tindak lanjut yang perlu diperhatikan oleh pengurus pondok pesantren. Hasil evaluasi ini sebagai umpan balik kepada pihak pondok untuk mengevaluasi pembelajaran yang selama ini berlangsung di pondok pesantren.

\section{KESIMPULAN}

Berdasarkan pada paparan data dan pembahasan diatas terkait manajemen sumberdaya santri di pondok Pesantren Baitul Arqom Balung bisa dikemukakan kesimpulan sebagai berikut :

1. Desain perencanaan sumberdaya Santri Pondok Pesantren Bairul Arqom Balung.

Pertama, Perencanaan sumber daya santri pondok pesantren Baitul Arqom selalu diadakan koordinasi terkait kekosongan sumberdaya santri di setiap tahunnya, baik dilakukan secara formal maupun non formal. Kedua, analisis kekosongan sumberdaya santri berdasarkan informasi yang didapat, analisis data dan pengalaman serta perkiran-perkiraan berdasarkan pengalaman. Ketiga, dari perencanaan sumber daya santri yang telah disusun itu dipastikan pondok pesantren Baitul Arqom tidak akan menolak semua santri yang akan belajar di pondok pesantren, mereka semua akan dibina dan dididik sesuai dengan peraturan Baitul Arqom.

2. Sistem rekrutmen dan seleksi sumberdaya Santri Pondok Pesantren Bairul Arqom Balung.

Pertaman, Pola rekrutmen di pondok pesantren Baitul Arqom Balung adalah pola eksternal pesantren (masyarakat luar pesantren). Kedua, Proses rekrutmen pondok pesantren baitul arqom yaitu santri mendaftar ke panitia pendaftaran dan mengisi serta melengkapi beberapa persyaratan. Ketiga, Proses rekrutmen santri dilakukan secara humanis dan tidak timbang pilih. Keempat, Hanya Seleksi administrasi yang dilakukan di pondok pesantren baitul arqom, tidak Menggunakan sistem gugur dalam proses seleksi, santri baru di tes atau di uji untuk mengetahui kualitas santri baru.

3. Proses orientasi dan penempatan sumberdaya Santri Pondok Pesantren Bairul Arqom Balung.

Pertama, Proses penyampaian orientasi terhadap Santri baru dilakukan dengan cara formal yaitu disebut pengenalan santri baru dan khutbatul arsy. Kedua, Tujuan orientasi di baitul arqom adalah untuk mengenalkan kultur dan pembelajran yang ada di pondok pesantren. Ketiga, Tes awal masuk yang dilakukan sebagai bahan pertimbangan santri baru untuk ditempatkan di kelas dan dikamar mana santri menginap. Keempat, ada dua tipe orientasi yang dilakukan di pondok pesantren yaitu induksi dan sosisalisi.

\section{Evaluasi sumberdaya Santri Pondok Pesantren Bairul Arqom Balung. \\ Pertama, Dalam menilai santri} pondok pesantren menggunakan penilaian akademis dan humanis. Kedua, Penilaian dilakukan dengan beberapa tes, ada tiga tes yang dilakukan pondok pesantren yaitu tes lisan, tes tulis, dan pengamatan setiap hari. Ketiga, semua elemen ikut dalam penilaian yaitu Guru, Wali Kelas, pengasuh santri dan pembimbing santri. Keempat, evaluasi sumberdaya santri ini bermanfaat untuk seberapa besar daya serap yang diperoleh.

\section{DAFTAR PUSTAKA}

Departemen Pendidikan Nasional, UU RI No. 20 tahun 2003 tentang Sistem Pendidikan Nasional, Jakarta : 
Departemen Pendidikan Nasional 2010

Fahmi, Irfan. (2011). Manajemen Kinerja; Teori dan Aplikasi. Bandung : Alfabeta

Jusmaliana. (2011). Pengelolaan Sumberdaya Insani. Jakarta : Bumi aksara

Moleong, Lexy. (2008). Metode Penelitian Kualitatif. Bandung: Remaja Karya

Hasibuan, Malayu S.P. (2011). Manajemen Sumber Daya Manusia. Jakarta : Bumi Aksara

Mastuki, H.S. (2010). Kebangkitan Kelas Menengah Santri : Dari Tradisionalisme, Liberalisme, Post-Tradisionalisme, Hingga Fundamentalisme, Banten : Pustaka Dunia

Meldona. (2009). Manajemen Sumber Daya Manusia Perspektif Integratif. Malang : UIN Malang Pres

Sadili, Samsudin. (2006). Manajemen Sumber Daya Manusia. Bandung : Pustaka Setia

Indrafacrudin, Soekarto. (2006). Bagaimana Memimpin Sekolah Yang Efektif. Bogor : Ghalia Indonesia

Siagian, Sondang P. (2008). Manajemen Sumberdaya Manusi., Jakarta : PT Bumi Aksara

Sonhaji, Soleh (2005). Konsep-Konsep Pengembangan Pondok Pesantren, dalam A. Halim (Eds), Manajemen Pesantren. Yogyakarta : Pustaka Pesantren

Soekarto. (2006). Bagaimana memimpin sekolah yang efektif. Bogor :

Ghalia Indonesia
Mondy, Wayne. (2008). Manajemen Sumberdaya Manusia Jilid 1 Edisi 10, Terj. Bayu Airlangga. Jakarta : Eirlangga 